\title{
PENGARUH IMPLEMENTASI LOAD BALANCING DAN TUNING WEB SERVER PADA RESPONSE TIME RASPBERRY PI
}

\author{
Dodon Turianto Nugrahadi ${ }^{1}$, Rudy Herteno ${ }^{2}$, Muhammad Anshari ${ }^{3}$ \\ 1,2,3 Prodi Ilmu Komputer FMIPA ULM \\ Jl. A. Yani Km 36 Banjarbaru, Kalimantan Selatan \\ Email: Dodonturianto@ulm.ac.id
}

\begin{abstract}
The rapid development of technology, the increase in web-based systems and development of microcontroller device, have an impact on the ability of web servers to respond in serving client requests. This study aims to analyze load balancing methods algoritma round robin and tuning that significant influence for the response time and the number of clients who are able to be handled in serving clients on the web server with microcontroller device. From this study with Stresstool testing the response time was 2064, 2331,4 and 1869,2ms for not using load balancing and 2270, 2306,2 and 2202ms with load balancing from 700 requests served by web servers. It can be concluded that web server response times that use load balancing are smaller than web servers without load balancing. Furthermore, using tuning with the response time obtained at 3103.4ms from 1100 requests. So, with tuning can reduce response time and increase the number of requests. With level significant level calculatio, have it khown that tuning configuration give significant effect for the response time and the number of clients in microcontroller.
\end{abstract}

Keywords: Web server, Raspberry, Load balancing, Response time, Stresstool.

\begin{abstract}
Abstrak
Perkembangan implementasi teknologi yang pesat, seiring dengan perkembangannya sistem berbasis web dan perangkat mikrokontroler, berdampak pada kemampuan web server dalam memberikan tanggap untuk melayani permintaan klien. Penelitian ini bertujuan untuk menganalisis metode load balance algoritma round robin dan tuning yang berpengaruh terhadap waktu tanggap dan banyaknya jumlah klien yang mampu ditangani dalam melayani klien pada web server dengan mikrokontroler. Dari penelitian ini dengan pengujian Stresstool didapatkan waktu tanggap sebesar 2331,4, 2064, 1869,2ms untuk tanpa load balancing dan 2270, 2306,2 dan 2202ms dengan load balancing dari 600 permintaan yang dilayani web server. Dapat disimpulkan bahwa waktu tanggap web server yang menggunakan load balancing lebih kecil dibandingkan web server yang tidak menggunakan load balancing. Selanjutnya menggunakan tuning dengan waktu tanggap sebesar 3103,4ms dari 1100 permintaan. Jadi, tuning dapat mempersingkat waktu tanggap dan meningkatkan jumlah permintaan yang dilayani web server. Selanjutnya dengan penghitungan tingkat pengaruh, bahwa diketahui konfigurasi load balancing algoritma round robin dan tuning memberikan pengaruh secara signifikan terhadap waktu tanggap dan jumlah permintaan pada mikrokontroler.
\end{abstract}

Kata kunci : Web server, Raspberry, Load balancing, Waktu tanggap, Stresstool, Jmeter, Klien

Pengaruh Load Balancing dan Tuning Web Server pada Response Time Raspberry Pi (Dodon T) |211 


\section{PENDAHULUAN}

Perkembangan teknologi yang pesat, seiring dengan meningkatnya perkembangan sistem berbasis web, menurut netcraft.com pada bulan maret 2016, tercatat ada sebanyak 171 juta situs yang aktif, penggunaan web server berbasis Nginx tercatat mengalami kenaikan sebanyak 669.000 situs dan mengalami penambahan sebanyak 15.000 komputer yang menjalankan web server ini, web server berbasis apache juga mengalami kenaikan sebanyak 447 komputer.

Penggunaan aplikasi web server cenderung dijalankan pada hardware yang berspesifikasi tinggi, kecenderungan ini dikarenakan adanya ekspektasi permintaan yang tinggi terhadap sebuah web server sehingga memerlukan hardware yang besar agar melayani permintaan dengan baik. Pada kenyataan dilapangan penggunaan aplikasi web server tidak akan menangani segitu banyak permintaan, sehingga tidak bakal memanfaatkan sepenuhnya potensi hardware yang dimilikinya. Hardware dengan spesifikasi yang tinggi biasa ditempatkan pada ruang server khusus.

Salah satu alternatif untuk menanggulangi kebutuhan akan spesifikasi hardware yang tinggi adalah dengan memanfaatkan mikrokontroler raspberry pi. Raspberry Pi merupakan komputer mini yang memiliki ukuran kecil yaitu sebesar ukuran kartu ATM tetapi mampu menjalankan tugas yang sama dengan komputer $P C$. Karena raspberry pi merupakan sebuah komputer mini maka dimungkinkan menjalankan aplikasi web server.

Seiring dengan meningkatnya permintaan terhadap akses sebuah web server, Pada penelitian Didik Aribowo (2013) menyebutkan, single server yang selalu menerima permintaan dari banyak pengguna, secara perlahan akan terjadi overload dan crash sehingga berdampak pada permintaan yang tidak dapat dilayani oleh single server [2].

Salah satu solusinya, menurut Taufik Febrianto (2014), teknik load balancing merupakan salah satu teknik yang digunakan untuk meningkatkan kinerja dan tingkat ketersediaan server, yaitu dengan membagi request yang datang ke beberapa server sekaligus, sehingga beban yang ditanggung oleh masing-masing server lebih ringan [3]. Selain itu menurut handoko (2017), rata-rata waktu respon minimal pada arsitektur yang tidak menggunakan load balancing lebih besar dibandingkan dengan arsitektur yang menggunakan load balancing [4]. Teknologi Load Balancing memiliki beberapa algoritma dalam mendistribusikan beban salah satunya adalah algoritma round robin. Algoritma Round robin melakukan pembagian beban secara bergiliran dan berurutan dari satu server ke server yang lain sehingga membentuk putaran.

Pada pendapat lain, menurut Xue Liu dkk (2003) Tuning merupakan salah satu cara untuk meningkatkan performansi sebuah web server, dengan cara mengoptimalkan pengaturan parameter konfigurasi dengan benar dapat meningkatkan kinerja, terutama pada beban kerja [5].

Implementasi load Balancing dan tuning mempengaruhi performansi jumlah waktu tanggap dan jumlah permintaan yang dapat dilayani sebuah web server, karena load balancing membagi setiap permintaan dan meneruskan ke web server, serta tuning dapat meningkatkan performansi web server. 


\section{METODE PENELITIAN}

Algoritma Round robin merupakan algoritma yang digunakan untuk metode load balancing dengan membagi beban ke server - server lain sehingga membentuk putaran. Algoritma round robin digunakan pada server untuk menyeimbangkan beban pada beberapa server. Penjadwalan algoritma round robin memberikan tugas-tugas ke semua bagian dalam bentuk matematika. Round robin memilih server dengan $\mathrm{i}=(\mathrm{i}+1) \bmod \mathrm{n}$ setiap kali, dimana $\mathrm{n}$ adalah jumlah server [1].

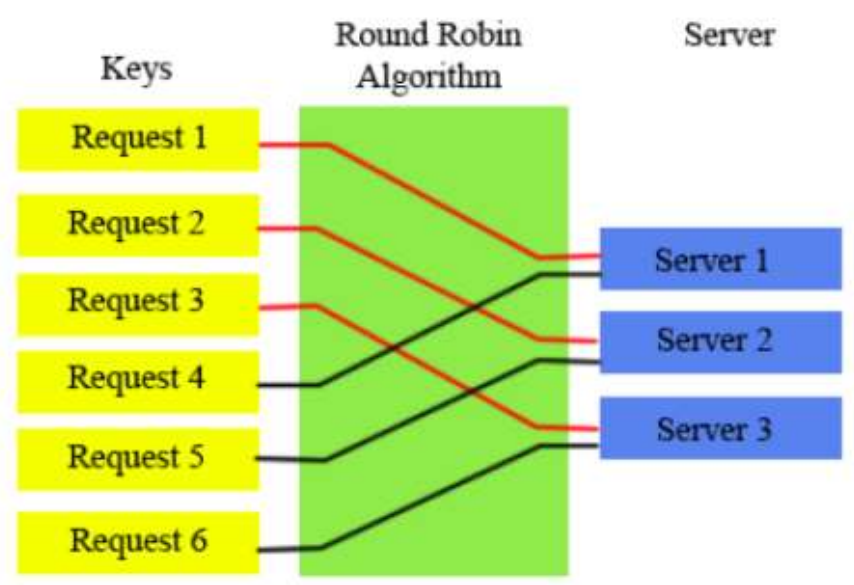

Gambar 1. Algroritma round robin.

\subsection{Perancangan Arsitektur}

Perancangan arsitektur tanpa menggunakan load balancing hanya mengunakan satu buah raspberry pi sebagai web server.

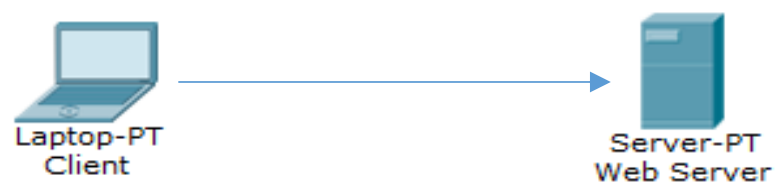

Gambar 1. Arsitektur web server tanpa menggunakan load balancing

Pada gambar 1, arsitektur dibuat dengan menggunakan satu unit raspberry pi yang berfungsi sebagai web server dan satu unit laptop yang berfungsi sebagai klienyang saling terhubung mengunakan media kabel UTP dengan konektor RJ 45. Arsitektur ini diimplementasikan pada skenario 1, 2 dan 3.

Perancangan arsitektur menggunakan load balancing mengunakan tiga buah raspberry pi, satu raspberry pi berfungsi sebagai balancer dan dua raspberry pi berfungsi sebagai web server. 


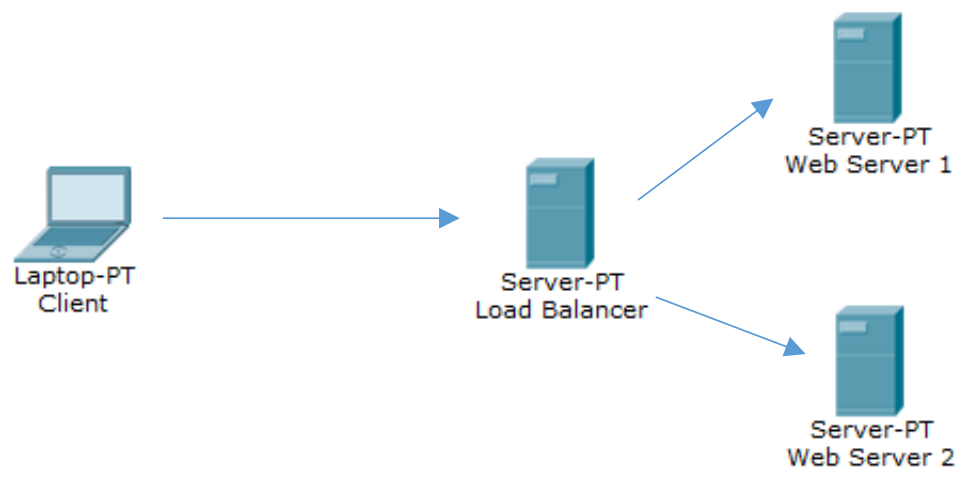

Gambar 2. Arsitektur web server menggunakan load balancing dengan algoritma Round robin

Pada gambar 2, arsitektur dibuat dengan 1 unit raspberry pi sebagai load balancing dan dua unit raspberry pi sebagai web server dan satu unit laptop sebagai klien yang saling terhubung menggunakan kabel UTP, konektor RJ45 dan Switch. Penggunaan kabel UTP, konektor RJ45 dan switch berpengaruh pada proses komunikasi data, akan tetapi tidak diperhitungkan dalam penelitian ini. Arsitektur ini diimplementasikan pada skenario 4, 5 dan 6.

Pada arsitektur web server yang tidak menggunakan load balancing, raspberry pi menggunakan sistem operasi Raspbian Stretch Lite dan menggunakan web server Nginx. Untuk laptop klien menggunakan sistem operasi windows 7 dari Microsoft. Setelah setiap raspberry pi selesai di instalasi, maka tahap selanjutnya adalah melakukan konfigurasi IP. Untuk Web server yang digunakan adalah 192.168.100.51 dengan netmask 255.255.255.0 dan gateway 192.168.100.1. Dan untuk laptop (PC) klien IP yang digunakan adalah 192.168.100.25 dengan netmask 255.255.255.0 dan gateway 192.168.100.1.

Pada arsitektur web server yang menggunakan load balancing dengan algoritma round robin. Web server yang diimplementasikan sebagai load balancer tersebut menggunakan Raspbian Stretch Lite dan Nginx. Dua raspberry pi berfungsi sebagai web server dan satu raspberry pi berfungsi sebagai load balancer, setelah diinstalasi, tahap selanjutnya adalah konfigurasi IP. Untuk raspberry pi pertama diberikan IP 192.168.100.51 netmask 255.255.255.0 dan gateway 192.168.100.1. Raspberry pi kedua diberikan IP 192.168.100.52 netmask 255.255.255.0 dan gateway 192.168.100.1. Untuk raspberry pi ketiga diberikan IP 192.168.100.53 netmask 255.255.255.0 dan gateway 192.168.100.1 sebagai load balancer.

\section{$2.2 \quad$ Skenario}

Pada tuning dilakukan berbagai skenario, tujuan melakukan skenario adalah melakukan pengujian arsitektur tanpa load balancing dan arsitektur menggunakan load balancing. Dalam Penelitian ini dilakukan sebanyak 6 skenario. Dalam skenario dilakukan perubahan konfigurasi tuning yang telah disesuaikan.

Pada skenario 1 merupakan pengujian dengan arsitektur tanpa load balancing dan tidak dilakukan perubahan pada parameter worker_processor, worker_connection, keepalive request dan timeout serta compression. Skenario 2 dilakukan pada arsitektur tanpa load balancing, dilakukan perubahan pada 
parameter worker_processor menjadi 4, worker_connection menjadi 1024, keepalive request dan timeout menjadi 320 dan 300s serta compression diaktifkan. Skenario 3 dilakukan pada aristektur tanpa load balancing,dilakukan perubahan pada parameter worker_processor menjadi 2, worker_connection menjadi 768, keepalive requestdan timeout menjadi 320 dan 300s. Skenario 4 dilakukan pada arsitektur menggunakan load balancing dengan tidak ada perubahan pada parameter worker_processor, worker_connection, keepalive request dan timeout serta compression. Skenario 5 dilakukan pada arsitektur menggunakan load balancing, dilakukan perubahan pada parameter worker_processor menjadi 4, worker_connection menjadi 1024, keepalive request dan timeout menjadi 320 dan 300s serta compression diaktifkan. Skenario 6 dilakukan pada aristektur menggunakan load balancing,dilakukan perubahan pada parameter worker_processor menjadi 2, worker_connection menjadi 768 , keepalive requestdan timeout menjadi 320 dan 300s.

Konfirgurasi ini berdasarkan buku pedoman dari web server nginx beberapa konfigurasi tuning yang berpengaruh terhadap peningkatan performa web server nginx. Berdasarkan beberapa percobaan awal dari penelitian ini, maka pada penelitian ini menggunakan parameter worker_processor, worker_connection, keepalive request, timeout dan compression sebagai parameter tuning. Parameter tersebut menggunakan nilai parameter maksimal dan parameter setengah dari maksimal. Untu memudahkan dalam membaca perubahan konfigurasi pada setiap skenario, perubahan konfigurasi disajikan dalam tabel, Berikut tabel perubahan konfigurasi yang dilakukan dalam penelitian ini :

Tabel 1. Konfigurasi skenario

\begin{tabular}{ccccccc}
\hline & \multicolumn{3}{c}{ Tanpa Load Balancing } & \multicolumn{3}{c}{ Menggunakan Load Balancing } \\
& $\begin{array}{c}\text { Skenario } \\
1\end{array}$ & Skenario 2 & Skenario 3 & Skenario 4 & Skenario 5 & Skenario 6 \\
\hline $\begin{array}{c}\text { Worker } \\
\text { Processor }\end{array}$ & Auto & 4 & 2 & Auto & 4 & 2 \\
$\begin{array}{c}\text { Worker } \\
\text { Connection }\end{array}$ & 768 & 1024 & 768 & 768 & 1024 & 768 \\
$\begin{array}{c}\text { Keepalive } \\
\text { Request }\end{array}$ & - & 320 & 320 & - & 320 & 320 \\
$\begin{array}{c}\text { Keepalive } \\
\text { Timeout }\end{array}$ & 65 & 300 & 300 & 65 & 300 & 300 \\
Compression & Off & On & On & Off & On & On \\
\hline
\end{tabular}

\subsection{Pengumpulan Data}

Pengumpulan data dilakukan dengan cara melakukan http request pada setiap skenario arsitektur web server dengan mengunakan software Jmeter. Perintah yang digunakan untuk melakukan http request yaitu dengan cara memasukkan Thread Group , number of thread, ramp-up period, dan loop count selanjutnya mengisi Jmeter element yaitu config element sebagai http request dan mengisi alamat web server, yang terakhir adalah menambahkan listener yaitu summary report. 
Proses toolsjmeter dengan mengirimkan permintaan kepada web server dimulai dari 100 dan meningkat dengan kelipatan 100 sampai ditemukan nilai permintaan yang menimbulkan kesalahan (error-rate> 0). Nilai permintaan error inilah yang diambil sebagai nilai permintaan maksimum.

\section{HASIL DAN PEMBAHASAN}

\section{$3.1 \quad$ Hasil}

Tabel 2. Hasil pengumpulan data arsitektur web server tanpa menggunakan load balancing algoritma round robin tanpa tuning skenario 1

\begin{tabular}{ccc}
\hline Permintaan & Average & Error \\
\hline 100 & 21,4 & $0 \%$ \\
200 & 72 & $0 \%$ \\
300 & 634 & $0 \%$ \\
400 & 1184,6 & $0 \%$ \\
500 & 1745,6 & $0 \%$ \\
600 & 2331,4 & $0 \%$ \\
700 & 2788,6 & $0 \%$ \\
800 & 3121 & $0 \%$ \\
900 & 2954,4 & $11.47 \%$
\end{tabular}

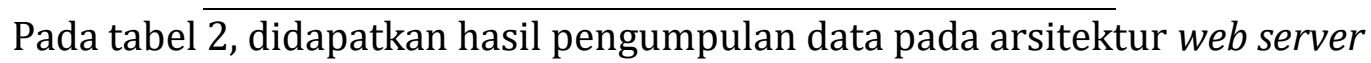
tanpa menggunakan load balancing dan tanpa tuning dengan data yang bervariasi pada setiap klien. Pada percobaan ini didapatkan maksimum permintaan yang dapat dilayani web server adalah sebesar 800 permintaan, dikarenakan nilai error $>0 \%$ pada permintaan 900 yaitu sebesar $11,47 \%$.

Tabel 3. Hasil pengumpulan data arsitektur web server tanpa menggunakan load balancing algoritma round robin dengan tuning skenario 2

\begin{tabular}{ccc}
\hline Permintaan & Average & Error \\
\hline 100 & 18,4 & $0 \%$ \\
200 & 110 & $0 \%$ \\
300 & 623,2 & $0 \%$
\end{tabular}




\begin{tabular}{ccc}
\hline Permintaan & Average & Error \\
\hline 400 & 1106,8 & $0 \%$ \\
500 & 1592,2 & $0 \%$ \\
600 & 2064 & $0 \%$ \\
700 & 2414,2 & $0 \%$ \\
800 & 2119,2 & $11,524 \%$ \\
\hline
\end{tabular}

Pada tabel 3, didapatkan hasil pengumpulan data pada arsitektur web server tanpa load balancing dan tuning skenario 2, dengan variasi data pada setiap klien. Pada percobaan ini didapatkan maksimum permintaan yang dapat dilayani web server adalah sebesar 700 permintaan, dikarenakan nilai error $>0 \%$ pada permintaan 800 yaitu sebesar 11,524\%.

Tabel 4. Hasil pengumpulan data arsitektur web server tanpa menggunakan load balancing algoritma round robin dengan tuning skenario 3

\begin{tabular}{ccc}
\hline Permintaan & Average & Error \\
\hline 100 & 21,4 & $0 \%$ \\
200 & 61,8 & $0 \%$ \\
300 & 436,2 & $0 \%$ \\
400 & 850,8 & $0 \%$ \\
500 & 1352 & $0 \%$ \\
600 & 1869,2 & $0 \%$ \\
700 & 2255,6 & $0 \%$ \\
800 & 2529,6 & $0 \%$ \\
900 & 2725,6 & $0 \%$ \\
1000 & 2967,2 & $0 \%$ \\
1100 & 3103,4 & $0 \%$ \\
1200 & 2905,2 & $10,5 \%$ \\
\hline
\end{tabular}

Pada tabel 4, didapatkan hasil pengumpulan data pada arsitektur web server tanpa menggunakan load balancing dan tuning skenario 3, dengan data yang bervariasi pada setiap klien. Pada percobaan ini didapatkan maksimum permintaan yang dapat dilayani web server adalah sebesar 1100 permintaan, dikarenakan nilai error $>0 \%$ pada permintaan 1200 yaitu sebesar $10,5 \%$. 
Tabel 5. Hasil pengumpulan data arsitektur web server menggunakan load balancing algoritma round robin tanpa tuning skenario 4

\begin{tabular}{ccc}
\hline Permintaan & Average & Error \\
\hline 100 & 30,4 & $0 \%$ \\
200 & 270,2 & $0 \%$ \\
300 & 709 & $0 \%$ \\
400 & 1238 & $0 \%$ \\
500 & 1764,6 & $0 \%$ \\
600 & 2270 & $0 \%$ \\
700 & 2544,4 & $0 \%$ \\
800 & 2959 & $4,15 \%$ \\
\hline
\end{tabular}

Pada tabel 5, didapatkan hasil pengumpulan data pada arsitektur web serverdengan menggunakan load balancing dan tuning skenario 4, dengan variasi data pada setiap klien. Pada percobaan ini didapatkan maksimum permintaan yang dapat dilayani web server adalah sebesar 700 permintaan, dikarenakan nilai error > $0 \%$ pada permintaan 800 yaitu sebesar $4,15 \%$.

Tabel 6. Hasil pengumpulan data arsitektur web server menggunakan load balancing algoritma round robin dengan tuning skenario 5

\begin{tabular}{ccc}
\hline Permintaan & Average & Error \\
\hline 100 & 30,6 & $0 \%$ \\
200 & 229,2 & $0 \%$ \\
300 & 750,2 & $0 \%$ \\
400 & 1159,6 & $0 \%$ \\
500 & 1424,2 & $0 \%$ \\
600 & 2306,2 & $0 \%$ \\
700 & 2376,2 & $7,9 \%$ \\
\hline
\end{tabular}

Pada tabel 6, didapatkan hasil pengumpulan data pada arsitektur web server dengan menggunakan load balancing dan tuning skenario 5, dengan variasi data pada setiap klien. Pada percobaan ini didapatkan maksimum permintaan yang dapat dilayani web server adalah sebesar 600 permintaan, dikarenakan nilai error $>0 \%$ pada permintaan 700 yaitu sebesar 7,9\%. 
Tabel 7. Hasil pengumpulan data arsitektur web server menggunakan load balancing algoritma round robin dengan tuning skenario 6

\begin{tabular}{ccc}
\hline Permintaan & Average & Error \\
\hline 100 & 50,4 & $0 \%$ \\
200 & 237,2 & $0 \%$ \\
300 & 668,4 & $0 \%$ \\
400 & 1244,8 & $0 \%$ \\
500 & 1556,4 & $0 \%$ \\
600 & 2202 & $0 \%$ \\
700 & 1994,2 & $11,3 \%$ \\
\hline
\end{tabular}

Pada tabel 7, didapatkan hasil pengumpulan data pada arsitektur web server dengan menggunakan load balancing dan tuning skenario 6, dengan variasi data pada setiap klien. Pada percobaan ini didapatkan maksimum permintaan yang dapat dilayani web server adalah sebesar 600 permintaan, dikarenakan nilai error $>0 \%$ pada permintaan 700 yaitu sebesar $11,3 \%$.

Tabel 8. Hasil Waktu Tanggap dan Jumlah Permintaan

Tanpa Load Balancing

Menggunakan Load Balancing

Permintaan

Skenario Skenario Skenario Skenario Skenario Skenario

1

23

4

5

6

\begin{tabular}{ccccccc}
\hline 100 & 21,4 & 18,4 & 21,4 & 30,4 & 30,6 & 50,4 \\
200 & 72 & 110 & 61,8 & 270,2 & 229,2 & 237,2 \\
300 & 634 & 623,2 & 436,2 & 709 & 750,2 & 668,4 \\
400 & 1184,6 & 1106,8 & 850,8 & 1238 & 1159,6 & 1244,8 \\
500 & 1745,6 & 1592,2 & 1352 & 1764,6 & 1424,2 & 1556,4 \\
600 & 2331,4 & 2064 & 1869,2 & 2270 & 2306,2 & 2202 \\
700 & 2788,6 & 2414,2 & 2255,6 & 2544,4 & - & - \\
800 & 3121,4 & - & 2529,6 & - & - & - \\
900 & - & - & 2725,6 & - & - & - \\
1000 & - & - & 2967,2 & - & - & - \\
\hline
\end{tabular}




\begin{tabular}{cccccccc}
\hline & \multicolumn{4}{c}{ Tanpa Load Balancing } & \multicolumn{3}{c}{ Menggunakan Load Balancing } \\
Permintaan & Skenario & Skenario & Skenario & Skenario & Skenario & Skenario \\
& 1 & 2 & 3 & 4 & 5 & 6 \\
\hline \multirow{2}{*}{1100} & - & - & 3103,4 & - & - & - \\
\hline
\end{tabular}

Pada tabel 8, didapatkan hasil pengumpulan data pada arsitektur web server tanpa dan dengan menggunakan load balancing dengan algoritma round robin dengan variasi data pada setiap klien. Kemudian berdasarkan grafik untuk mempermudah melihat data yang didapatkan.

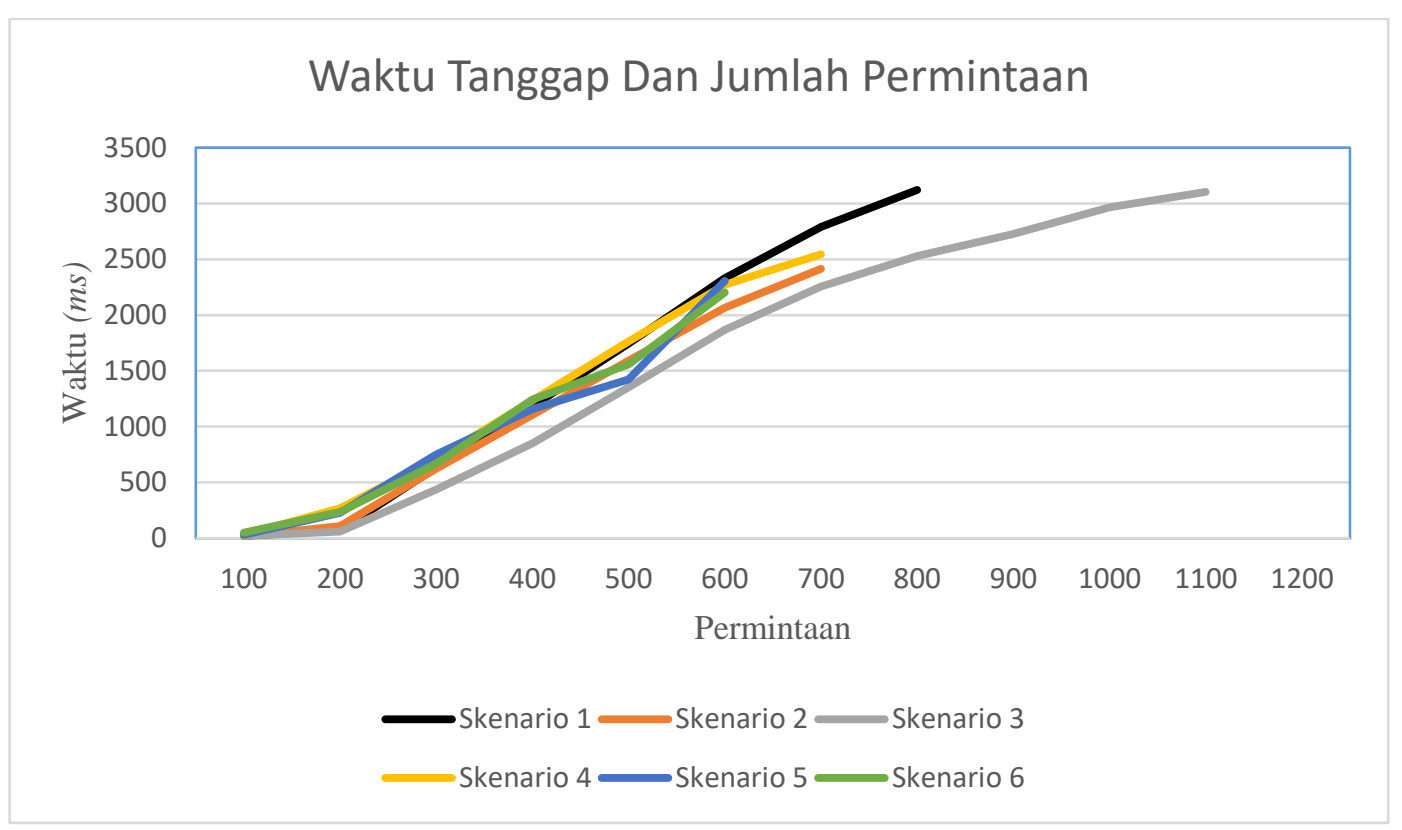

Gambar 3. Grafik hasil pengumpulan data waktu tanggap dan jumlah permintaan

\subsection{Pembahasan}

\subsubsection{Waktu Tanggap}

Analisis waktu tanggap bertujuan untuk mengetahui pengaruh penggunaan load balancing algoritma round robin dan tuning. Pertama arsitektur web server yang tidak menggunakan load balancing dibuat sesuai dengan gambar 1. Kemudian dibuat arsitektur yang ke dua sesuai dengan gambar 2 yaitu arsitektur web server yang menggunakan load balancing dengan algoritma round robin. Setelah kedua arsitektur dibuat, dilakukan pengambilan data dengan cara melakukan load test dengan tools penguji. Hasil yang didapat dari tahap pengambilan data dapat dilihat pada tabel 2 .

Waktu tanggap adalah waktu tanggap yang diterima oleh klien ketika mengakses sebuah web server. Pada tabel 2, diambil data sebanyak 6 variasi jumlah permintaan dari hasil waktu tanggap yang dihasilkan dari klien yang mengakses web server. 


\section{Tabel 9. Hasil Waktu Tanggap}

Tanpa Load Balancing

Permintaan

\begin{tabular}{ccccccc} 
& Skenario & Skenario & Skenario & Skenario & Skenario & Skenario \\
& 1 & 2 & 3 & 4 & 5 & 6 \\
\hline 100 & 21,4 & 18,4 & 21,4 & 30,4 & 30,6 & 50,4 \\
200 & 72 & 110 & 61,8 & 270,2 & 229,2 & 237,2 \\
300 & 634 & 623,2 & 436,2 & 709 & 750,2 & 668,4 \\
400 & 1184,6 & 1106,8 & 850,8 & 1238 & 1159,6 & 1244,8 \\
500 & 1745,6 & 1592,2 & 1352 & 1764,6 & 1424,2 & 1556,4 \\
600 & 2331,4 & 2064 & 1869,2 & 2270 & 2306,2 & 2202
\end{tabular}

Untuk mempermudah pembahasan, maka data disajikan dalam bentuk grafik. Perbandingan waktu tanggap dapat terlihat pada gambar 4 .

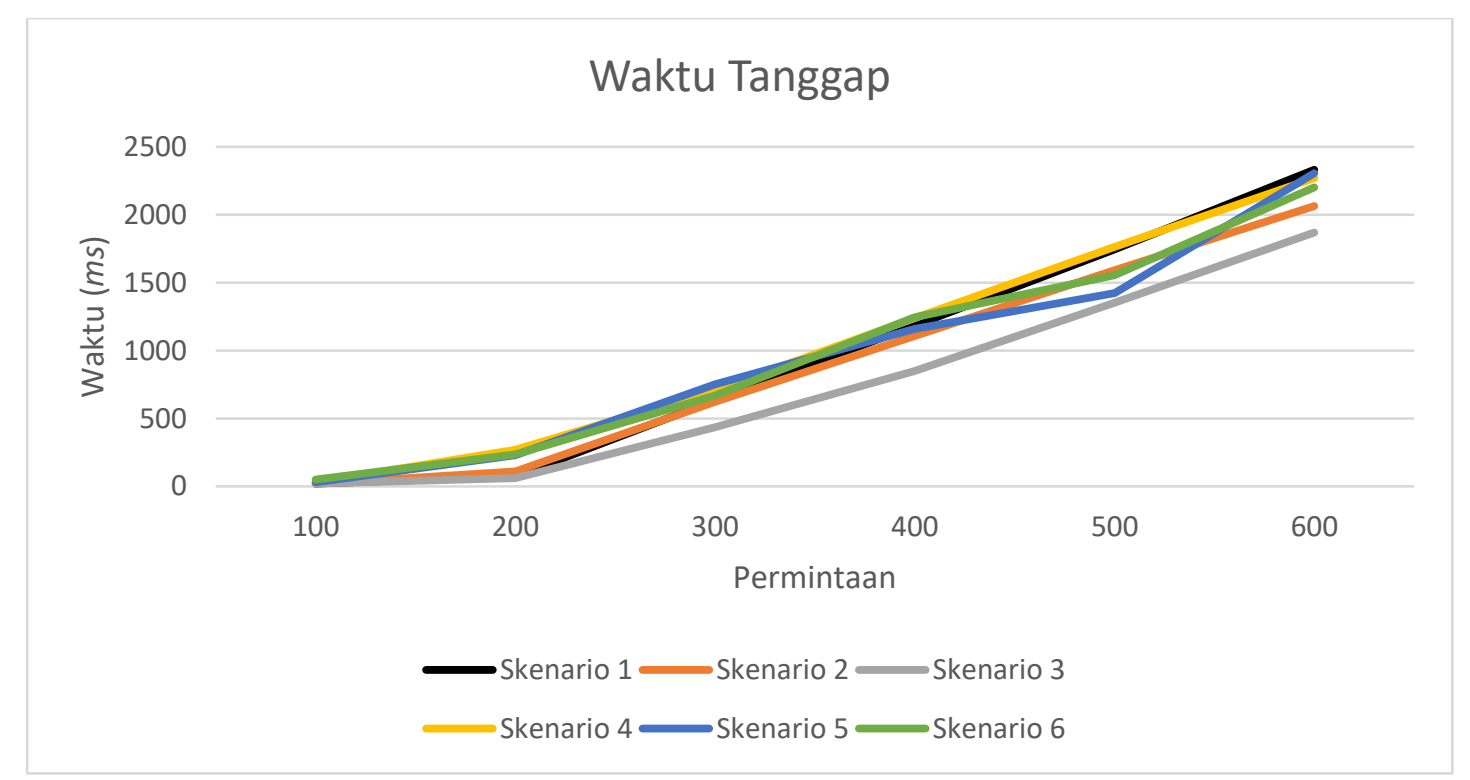

Gambar 4. Grafik perbandingan waktu tanggap

Pada gambar 4, terlihat bahwa pada tiap variasi jumlah permintaan, waktu tanggap pada arsitektur web server yang menggunakan load balancing algoritma round robin dan tuning lebih besar dibandingkan dengan arsitektur web server yang tanpa load balancing algoritma round robin dan arsitektur web server tanpa load balancing dengan tuning.

Adapun analisis perhitungan Anova untuk waktu tanggap rata-rata menggunakan input range, diisi dengan tabel 9 dengan nilai $\alpha=0,05$ digunakan sebagai taraf signifikansi. Perhitungan Anova mengacu pada tinjauan pustaka, sehingga hasil perhitungan menggunakan Anova untuk hasil waktu tanggap. Diketahui nilai PValue $=0,000142$, dimana skenario $<0,05$ dengan demikian dapat dikatakan setiap 
skenario implementasi load balancing algoritma round robin dan tuning berpengaruh terhadap waktu tanggap.

\subsubsection{Permintaan}

Jumlah Permintaan dikatakan maksimum jika terjadi nilai Error $>0$. Pada tabel 2 dapat dilihat jumlah permintaan maksimum yang dapat dilayani web server sebesar 800 klien pada skenario 1, 700 klien pada skenario 2, 1100 pada skenario 3, 700 pada skenario 4, 600 pada skenario 5 dan 600 pada skenario 6. Pada saat pengujian terjadi kenaikan cpu yang mengakibatkan terjadinya error. Terlihat pada skenario 3 terdapat kenaikan sebesar 500 klien atau sebesar $83 \%$, dengan ini dapat dikatakan skenario atau tuning berpengaruh terhadap jumlah permintaan yang dapat dilayani web server. Untuk mempermudah pembahasan, maka data disajikan dalam bentuk grafik. Perbandingan jumlah klien dapat terlihat pada gambar 4 .

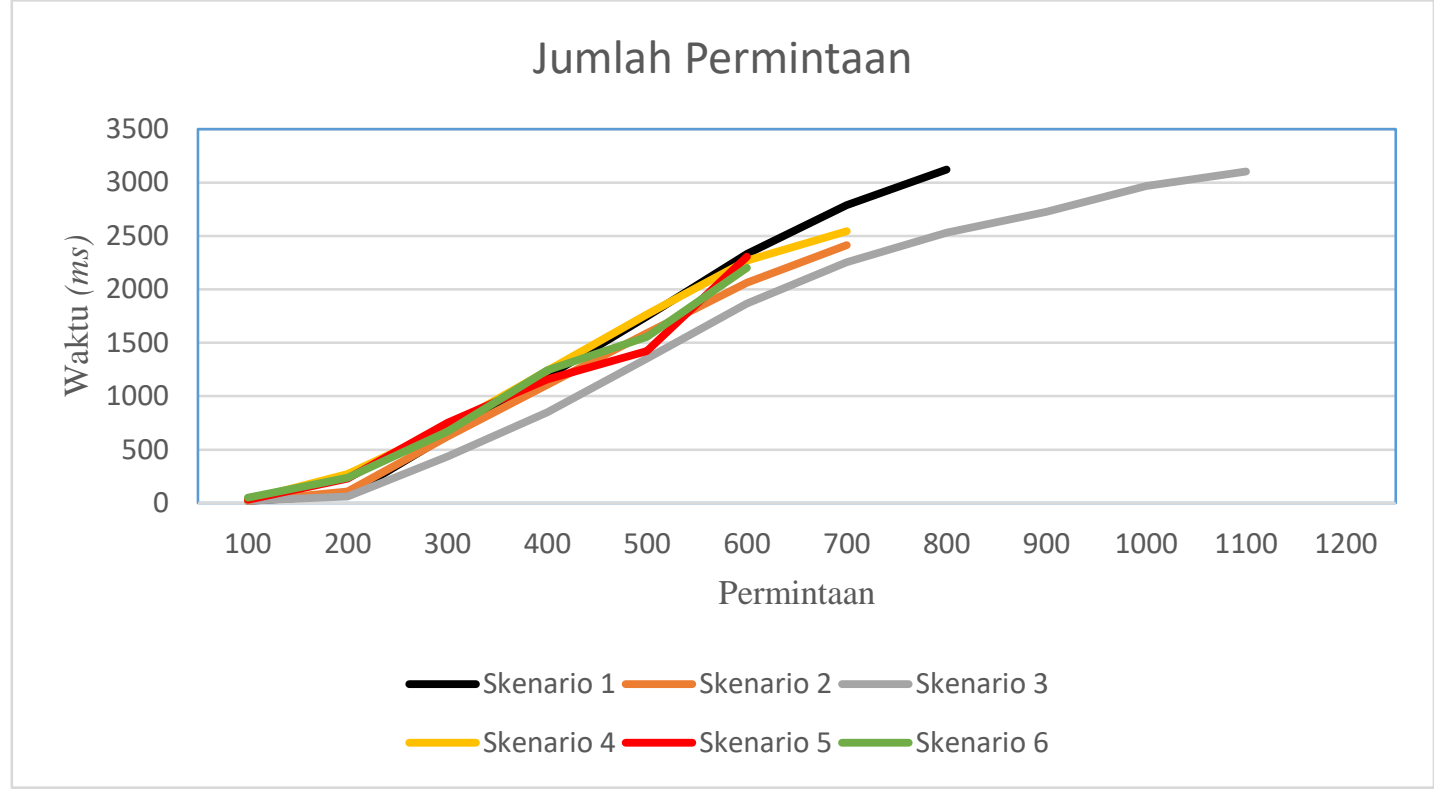

Gambar 5. Grafik jumlah permintaan yang dapat dilayani web server

\section{SIMPULAN}

Berdasarkan hasil penelitian maka diperoleh kesimpulan dari hasil pembahasan sebagai berikut :

a. Waktu tanggap pada arsitektur tanpa load balancing sebesar 2331,4ms pada skenario 1, 2414,2 $\mathrm{ms}$ pada skenario 2, 2255,6 $\mathrm{ms}$ dan pada skenario 3. Sedangkan Waktu tanggap pada arsitektur menggunakan load balancing 2544,4 $m s$ pada skenario 4, 2376,2 $m s$ pada skenario 5 dan $2202 m s$ pada skenario 6

b. Jumlah permintaan yang dapat ditangani web server sebesar 800 pada skenario 1, 700 pada skenario 2, 1100 pada skenario 3, 700 pada skenario 4, 600 pada skenario 5 dan 600 pada skenario 6 .

c. Implementasi load balancing algoritma round robin dan tuning berpengaruh pada waktu tanggap web server nginx dengan P-Value $=0,000142$, dan implementasi tuning pada web server dapat meningkatkan permintaan hingga $83 \%$. 


\section{DAFTAR PUSTAKA}

[1] Andarrachmi Annisa. 2014. "ImplementasiLoad Balancing DanVirtual Machine dengan AlgoritmaRound Robin Pada Sistem Informasi Penerimaan Pegawai Bppt". Badan Pengkajian dan Penerapan Teknologi (BPPT).

[2] Aribowo Didik dan Achmad Affandi. 2013. "Optimalisasi Cluster Server Lms Dan Iptv Dengan Variasi Algoritma Penjadwalan". Telekomunikasi Multimedia Teknik Elektro ITS, Surabaya, Seminar Nasional Teknologi Informasi dan Multimedia 2013 STMIK AMIKOM Yogyakarta, 19 Januari.

[3] Febrianto, Taufik. 2014. "Analisa Load Balancing Dengan Metode LVS Direct Routing Menggunakan Algoritma Round Robin dan Least Connection". Universitas Sebelas Maret: Surabaya.

[4] Handoko, Dodon T. N., Ichsan Ridani. 2017. "Implementasi Dan Pengujian Performansi Load Balancing Dengan Algoritma Leastconn Pada Database Server". Jurnal Elektronik Nasional Teknologi dan Ilmu Komputer (JENTIK)

[5] Liu Xue, dkk. 2003. "Online Respone Time Optimization Of Apache Web Server". Berlin: K. Jeffay, I. Stoica, and K. Wehrle (Eds.): IWQoS 